\title{
ADSORPTION OF HEAVY METAL ON ACTIVE CARBON DERIVED FROM COCONUT LEAVES AGRO-WASTE
}

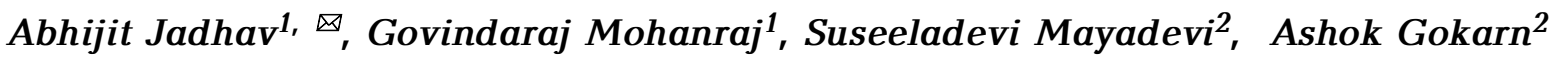

https://doi.org/10.23939/chcht14.04.553

\begin{abstract}
In this paper activated carbon is prepared from coconut leaves by chemical activation during slow pyrolysis at $673 \mathrm{~K}$ in an inert atmosphere. Activated carbon is prepared in the stiochiometric ratio of $1: 1\left(\mathrm{CL}_{1}\right)$, 2:1 $\left(\mathrm{CL}_{2}\right)$ and 3:1 $\left(\mathrm{CL}_{3}\right)$. Optimized 3:1 ratio is preferable for further study. BET surface area of $\mathrm{CL}_{3}$ activated carbon was found $1060.57 \mathrm{~m}^{2} / \mathrm{g}$. It is greater than those of $\mathrm{CL}_{1}$ and $\mathrm{CL}_{2}$. The batch sorption study experiments were conducted with respect to solute concentration of 2.5$122.8 \mathrm{mg} / 1$ and solution temperature of $313-343 \mathrm{~K}$. The Langmuir, Freundlich and Temkin isotherm studies were conducted. The experimental data fitted very well for the pseudo-first order and pseudo-second-order. The results have established good potentiality for the $\mathrm{CL}_{3}$ activated carbon to be used as a sorbent for the removal of lead from wastewater.
\end{abstract}

Keywords: $\mathrm{Pb}(\mathrm{II})$, coconut leaves, pseudo-first order, second-order, Langmuir isotherm, Freundlich isotherm, Temkin isotherm.

\section{Introduction}

The most universal problem in environmental pollution is water pollution. The discharge of heavy metals into water-courses has become the pollution problem and is affecting the quality of water and health mainly due to their non-degradability and toxicity. Numerous metals such as, copper $(\mathrm{Cu})$, lead $(\mathrm{Pb})$, manganese $(\mathrm{Mn})$, mercury $(\mathrm{Hg})$, etc. are known to be significantly toxic [1]. Furthermore, heavy metal contamination of drinking water and wastewater is a serious problem [2]. Thus, adsorption process is referred as the most effective technique for heavy metals removal from waste streams [3]. Removal of metal ions from aqueous solutions by adsorption on abundant and low-cost adsorbents is one of the possibilities [4]. Various techno-

\footnotetext{
${ }^{1}$ Department of Chemical Engineering, Birla Institute of Technology,

Mesra, Ranchi, India

${ }^{2}$ Department of Chemical Engineering, National Chemical Laboratory,

Pune, India

asj.paper@gmail.com

() Jadhav A., Mohanraj G., Mayadevi S., Gokarn A., 2020
}

logies are available for water treatment including the use of activated carbon [5]. Biomass waste activated carbon is the most widely used adsorbent for this treatment. It is assumed that the activated carbon removes metal ion, which is happening due to a surface complex formation [6]. The ability of activated carbon to remove metal ions from solution depends on the textural properties of the activated carbon, including total surface area and pore size, and its surface chemistry based on heteroatom concentrations. The surface chemistry can be inferred from carbon $\mathrm{pH}$ [7]. The activated carbons prepared from lignocellulosic materials are good absorbents. These materials were prepared from coconut shell [8], coffee residue [9], apple pulp [10], tamarind wood [4, 11], hazelnut husks [12], cones of the European Black pine [13], palm shell [14], and longan seed [15].To improve the sorption capacity of these biomaterials, the agricultural wastes were converted to activated carbon. In this paper the removal of heavy metals using adsorbents is performed in batch. Coconut leaves derived activated carbon is used for removal of $\mathrm{Pb}$ from $\mathrm{PbCl}_{2}$ solution. The batch adsorption technique using activated carbon has been studied by many authors $[2,4,8-13,16]$. In this research, the batch adsorption of lead performed by coconut leaves activated carbon was studied to determine the maximum uptake of lead ion. The activated carbon in laboratory scale is manufactured by chemical activation method during slow pyrolysis at $673 \mathrm{~K}$ denoted as onestage process [4]. One-step procedure appears to be preferable because of lower activation temperature used, which reduces production costs in term of energy and time saving. This process results in activated carbon with high adsorption capacity [5].

\section{Experimental}

\subsection{Materials}

The adsorbents were prepared from coconut leaves. Adsorbate solutions were prepared from lead chloride $\left(\mathrm{PbCl}_{2}\right.$, molecular weight of $\left.278.1 \mathrm{~g} / \mathrm{mol}\right)$, purchased from 
$\mathrm{M} / \mathrm{s}$. Thomas Baker, India. Metal removed is lead $\left(\mathrm{Pb}^{2+}\right)$. Chemical activation utilizes chemicals like phosphoric acid $\left(\mathrm{H}_{3} \mathrm{PO}_{4}\right)$ were purchased from M/s. Thomas Baker, India.

\subsection{Preparation and Analyses of Activated Carbon}

Raw coconut leaves based activated carbon (Fig. 1) was used for adsorption in this work. The activated carbon of $300 \mathrm{~g}$ batch size with impregnation ratio of $1: 1,2: 1$ and $3: 1$ was prepared and dried at the heating rate $3 \mathrm{~K} / 10 \mathrm{~min}$ in the presence of $\mathrm{N}_{2}$ flow $(3 \mathrm{ml} / \mathrm{min})$. The heating continued up to final temperature of $673 \mathrm{~K}$ for $90 \mathrm{~min}$. The carbon was left to be cooled and then was washed with distilled water, dried at $383 \mathrm{~K}$ and stored in stopper bottles. The samples were given the abbreviations $\mathrm{CL}_{1}$, $\mathrm{CL}_{2}$, and $\mathrm{CL}_{3}$ according to impregnation ratio. Before the experiments the samples were sieved and particles of 105 micron were used.

The surface area of the activated carbon was measured by BET (Brunauer-Emmett-Teller nitrogen adsorption technique) [3-7]. The physicochemical characteristics were determined for these activated carbons. $\mathrm{H}_{3} \mathrm{PO}_{4}$ was used as activating agent [9]. Determination of surface area of adsorbent is accomplished by using $\mathrm{N}_{2}$ adsorption.

The morphology of the prepared activated carbon surface was examined using scanning electron micrographs. These images provide positive reception of the porosity of adsorbents and consequently their ability to adsorb.

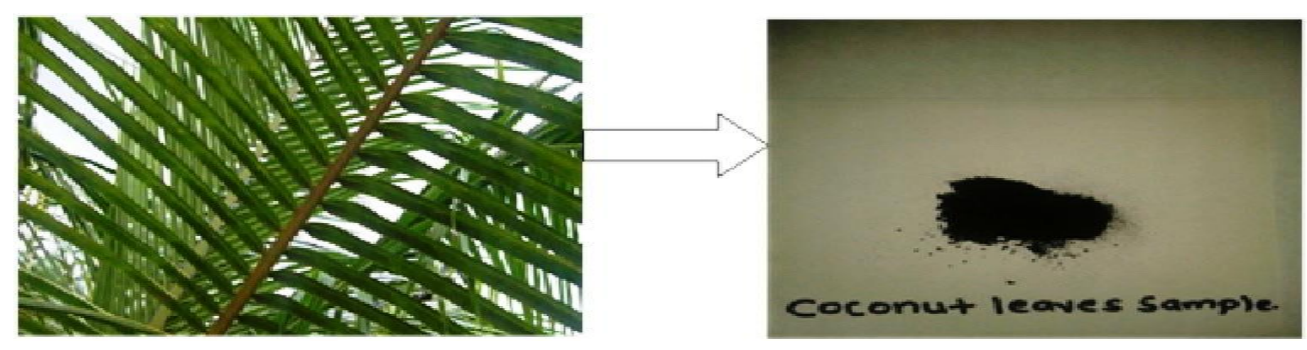

Fig. 1. Coconut leaves derived activated carbon

\subsection{Absorbate}

Stock solutions of $\mathrm{PbCl}_{2}$ (1000 ppm) for adsorption study was prepared from solid powders of pure metal salts (Thomas Baker Pvt Ltd, India) [6].

\subsection{Batch Adsorption}

Adsorption was performed in batch where $2 \mathrm{~g}$ of activated carbon was interacted with $40 \mathrm{~cm}^{3}$ of dye wastewater and allowed to stand for $30 \mathrm{~min}$. It was filtered using whatman filter paper (No. 42). The process was carried out for $60,90,120$ and $150 \mathrm{~min}$. The concentration of lead in the wastewater was determined before and after interaction with the activated carbon by a bulk scientific atomic absorption spectrophotometer (MODEL 210VGP). $20 \mathrm{mg}$ of the adsorbent in $25 \mathrm{ml}$ reagent bottles containing $10 \mathrm{ml}$ of lead solution (30 ppm) were mixed and placed in the shaker at constant temperature for different time intervals. The adsorbent was finally removed by filtration and $\mathrm{Pb}(\mathrm{II})$ chloride concentration was determined. The contact time required for complete metal adsorption was determined and utilized in the remaining tests.

\subsection{Surface Area Analysis}

The surface area of the activated carbon was measured by BET (Brunauer-Emmett-Teller nitrogen adsorption technique) [3, 7]. The physicochemical characteristics were determined for these activated carbons. $\mathrm{H}_{3} \mathrm{PO}_{4}$ was used as activating agent [9]. Determination of surface area of adsorbent is accomplished by using $\mathrm{N}_{2}$ adsorption. The surface areas and pore volumes of adsorbents are represented in Table 1. Coconut leaves $\left(\mathrm{CL}_{3}\right)$ has the highest surface area and pore volume. The surface areas of different carbons follow the order: $\mathrm{CL}_{3}>\mathrm{CL}_{2}>\mathrm{CL}_{1}$. $\mathrm{CL}_{3}$ exhibits similar nitrogen adsorption capacity at relative pressure up to 0.9 . The presence of micropores contributed to the high surface area of $\mathrm{CL}_{3}$. Thus $\mathrm{CL}_{3}$ is adapted for further study.

Table 1

Surface area and pore volume of adsorbents

\begin{tabular}{|c|c|c|}
\hline Adsorbents & $\begin{array}{c}\text { Surface area, } \\
\mathrm{m}^{2} / \mathrm{g}\end{array}$ & $\begin{array}{c}\text { Pore volume, } \\
\mathrm{cm}^{3} / \mathrm{g}\end{array}$ \\
\hline Coconut leaves $(1: 1)$ & 760.54 & 0.5430 \\
\hline Coconut leaves $(2: 1)$ & 1003.90 & 0.4589 \\
\hline Coconut leaves $(3: 1)$ & 1060.57 & 0.6697 \\
\hline
\end{tabular}

\subsection{SEM Analysis}

The morphology of the prepared activated carbon surface was examined using scanning electron micrographs. These images provide positive reception of the porosity of adsorbents and consequently their ability to adsorb. $\mathrm{CL}_{3}$ has small cavities with micro pores found on 
the surface due to phosphoric acid treatment. SEM analysis represents that coconut leaves derived activated carbon has sand, fiber-like structure.

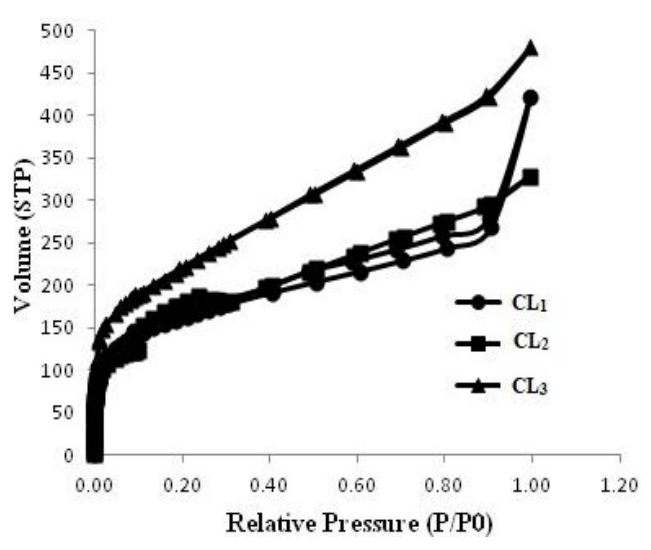

Fig. 2. $\mathrm{N}_{2}$ adsorption-desorption isotherm

SEM image shows fiber-like sand sheet like structure, which indicates that the adsorption capacity of active carbon in turn will help to describe the adsorption kinetics. The SEM 3D is shown in Fig. 4.

\subsection{Kinetic Models}

In order to investigate the reaction mechanism, the pseudo-first order kinetic model and the pseudo-second order kinetic model studies were performed. The kinetic model for sorption analysis is the pseudo first order rate expression of Lagergren [10] in the form:

$$
\frac{d q}{d t}=k_{1}\left(q_{e}-q_{t}\right)
$$

Integrating this for the boundary conditions $t=0$ to $t=t$ and $q_{t}=0$ to $q_{t}=q_{t}$, Eq. (1) may be rearranged for linearized data plotting as shown by Eq. (2). The first order kinetic equation [11] may be expressed as:

$$
\log \left(q_{e}-q_{t}\right)=\log q_{e}-\frac{k_{1} t}{2.303}
$$

where $q_{e}$ is the amount of adsorbate adsorbed at equilibrium state, $\mathrm{mg} / \mathrm{g} ; q_{t}$ is amount of solute sorbed on the surface of the sorbent at any time $t, \mathrm{mg} / \mathrm{g}, k_{l}$ is the rate constant for pseudo-first order adsorption, $1 / \mathrm{min}$.

The values of $\log \left(q_{e}-q_{t}\right)$ were linearly correlated with $t$. The plot of $\log \left(q_{e}-q_{t}\right)$ vs. $t$ gives a linear relationship from which $k_{l}$ and $q_{e}$ are determined from the slope and intercept of the plot, respectively.
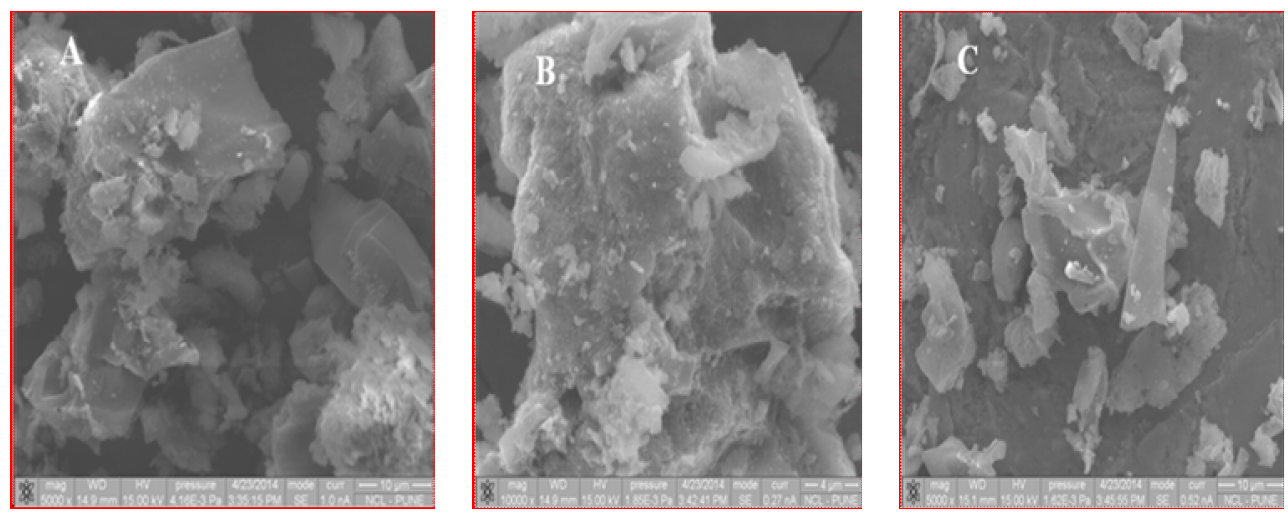

Fig. 3. SEM images of adsorbents with different acid/adsorbent ratio:

$\mathrm{CL}_{1}(\mathrm{~A}) ; \mathrm{CL}_{2}(\mathrm{~B})$ and $\mathrm{CL}_{3}(\mathrm{C})$ (magnification of $5000 \times$ )

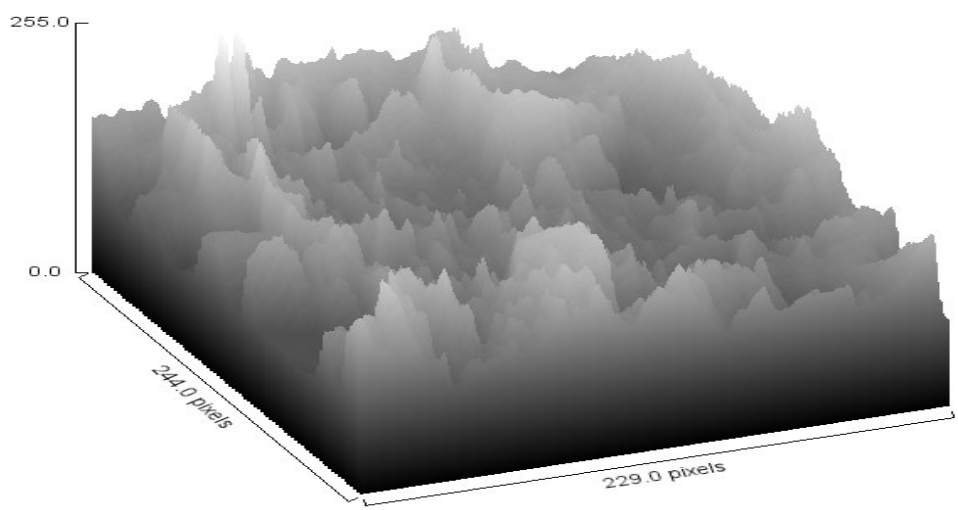

Fig. 4. SEM 3D surface plot of coconut leaves $\mathrm{CL}_{3}$ 
To describe lead adsorption, the modified pseudosecond order kinetic equation is expressed as [12]:

$$
\frac{d q_{t}}{d t}=k_{2}\left(q_{e}-q_{t}\right)^{2}
$$

where $k_{2}$ is the rate constant for the pseudo-first order adsorption, $\mathrm{g} / \mathrm{mg} \cdot \mathrm{min}$.

The plot $t / q v s$. $t$ of the above equation gives a linear relationship with a slop of $\frac{1}{q_{e}}$ and an intercept of $\frac{1}{k_{2} q_{e}^{2}}$

$$
\frac{1}{\left(q_{e}-q_{t}\right)}=\frac{1}{q_{e}}+k_{2} t
$$

Rearranging the terms in the above equation we get:

$$
q_{t} \frac{t}{\frac{1}{k_{2} q_{e}^{2}}+\frac{1}{q_{e}}}
$$

which is the integrated rate law for the pseudo-second order reaction. This has a linear form is given below:

$$
\frac{t}{q_{t}}=\frac{t}{k_{2} q_{e}^{2}}+\frac{1}{q_{e}} t
$$

Applying the limit $(q / t) \rightarrow 0$, the plot $t / q v s$. $t$ of the above equation gives a linear relationship with a slop of $\frac{1}{q_{e}}$ and an intercept of $\frac{1}{k_{2} q_{e}^{2}}$.

\subsection{Isotherms Modeling}

\subsubsection{Langmuir isotherm model}

The empirical Langmuir equation is given by the following equation:

$$
q_{e}=\frac{q_{m} K_{L} C_{e}}{\left(1+K_{L} C_{e}\right)}
$$

where $q_{e}$ is the equilibrium metal concentration on the adsorbent, $\mathrm{mg} \mathrm{g}^{-1} ; C_{e}$ is the equilibrium metal concentration in solution, $\mathrm{mg} \cdot \mathrm{l}^{-1} ; q_{m}$ is the monolayer capacity of the adsorbent, $\mathrm{mg} \mathrm{g}^{-1} ; K_{L}$ is the Langmuir constant, related to energy of adsorption, $1 \cdot \mathrm{mg}^{-1}$;

The linear form of the equation can be written as:

$$
-\frac{C_{e}}{q_{e}}=\frac{C_{e}}{q_{m}}+\frac{1}{K_{L} q_{m}}
$$

The values of $K_{L}$ and $q_{m}$ were determined from the slope and intercept of the representation $1 / q_{\mathrm{e}} v s .1 / C_{e}$, respectively. To determine if adsorption process is favorable or unfavorable for Langmuir type adsorption process, Langmuir isotherm is then classified using a dimensionless constant separation factor $R_{L}$, which can be defined as:

$$
R_{L}=\frac{1}{1+K_{L} C_{m}}
$$

where $C_{m}$ is the maximum initial metal concentration, $\mathrm{mg} \cdot \mathrm{l}^{-1}$. The values of this parameter indicated the shape of the isotherm, in which $R_{L}>1$ is unfavorable, $R_{L}=1$ is linear, $0<R_{L}<1$ is favorable, and $R_{L}=0$ is irreversible [16].

\subsubsection{Freundlich isotherm}

The Freundlich adsorption isotherm is applied to know the non-ideal adsorption on heterogeneous surfaces and multilayer adsorption. It is expressed by the following equation [8]:

$$
q_{e}=K_{F} C_{e}^{1 / n}
$$

where $q_{e}$ is the amount of metal adsorbed per unit of adsorbent, $\mathrm{mg} \mathrm{g}^{-1} ; C_{e}$ is the concentration of non-retained dye at equilibrium, $\mathrm{mg}^{-1} ; K_{F}\left(\mathrm{mg}^{(1-1 / n)} / \mathrm{g}^{1 / n}\right)$ and $1 / n$ are Freundlich empirical parameters relating to multilayer adsorption capacity and adsorption intensity, respectively.

For a suitable adsorption system $1 / n$ values varies between 0 and 1. Linear form of the Freundlich isotherm model is given by Eq. (6). The values of $K_{F}$ and $1 / n$ are obtained from the linear plot of $\ln q_{e} v s . \ln C_{e}[11,16]$ :

$$
\ln q_{e}=\ln K_{F}+\frac{1}{n} \ln C_{e}
$$

As implied in the equation, its derivation characterized by a uniform distribution of binding energies (up to some maximum binding energy) is plotted as sorbed quantity $q_{e}$ against $\ln C_{e}$ and the constants were determined from the slope and intercept. The model is given by the following equation:

$$
q_{e}=\frac{R T}{b} \ln \left(A_{T} C_{e}\right)
$$

Linearized form can be written as

$$
q_{e}=B \ln A_{T}+B \ln C_{e}
$$

where $B=\frac{R T}{b}$ is a constant related to heat of sorption, $\mathrm{J} / \mathrm{mol} ; A_{T}$ is Temkin isotherm equilibrium binding constant, $1 / \mathrm{g} ; b$ is Temkin isotherm constant; $R$ is universal gas constant equal to $8.314 \mathrm{~J} / \mathrm{mol} / \mathrm{K} ; T=298 \mathrm{~K}$.

\subsubsection{Equilibrium studies}

Adsorption equilibrium studies were conducted at initial lead solution $\mathrm{pH}$ of 4-7. Equilibrium data were obtained by adding $0.5-2 \mathrm{~g}$ of $\mathrm{CL}$ active carbon into a series of conical flasks each filled with $10 \mathrm{ml}$ of lead solution (5 ppm). The conical flasks covered with aluminum foil were placed in a thermostatic shaker for $4 \mathrm{~h}$ at $301 \mathrm{~K}$. The removal efficiency of lead on CL carbon $\left(R_{E}, \%\right)$, the sorption capacity $(q)$ and distribution ratio $\left(C_{d}\right)$ were calculated from following equations.

$$
R_{E}=\frac{C_{\text {in }}-C_{\text {out }}}{C_{\text {in }}} \cdot 100 \%
$$




$$
\begin{aligned}
& q=\frac{V\left(C_{\text {in }}-C_{\text {out })}\right.}{m} \\
& C_{d}=\frac{V_{s}}{V_{m}}
\end{aligned}
$$

where $C_{\text {in }}$ and $C_{\text {out }}$ are the initial and final concentrations of lead in aqueous solution, respectively, $\mathrm{mg} / \mathrm{l} ; V$ is the volume of the solution, $\mathrm{ml} ; m$ is the weight of the adsorbent, mg; $V_{s}$ is an amount of sorbed adsorbate; $V_{m}$ is an amount of adsorbate in solution.

\section{Results and Discussion}

Preliminary experiments show that coconut leaves $\left(\mathrm{CL}_{3}\right)$ derived activated carbon gives the highest surface area compared to other carbon adsorbents $\left(\mathrm{CL}_{1}, \mathrm{CL}_{2}\right)$. Therefore, $\mathrm{CL}_{3}$ carbon was selected for detailed experimental investigations. The aim was to find out the effect of various parameters on its affinity towards the uptake of lead chloride $\left(\mathrm{PbCl}_{2}\right)$.

\subsection{The Effect of Initial pH of Lead Ion Solution}

Initial $\mathrm{pH}$ and initial lead concentration of lead decides the removal percentage of lead ions. It was also shown that the lead concentration from the solution with initial $\mathrm{pH} 4$ is relatively higher than that at $\mathrm{pH} 7$. The lowest lead concentrations in the $\mathrm{PbCl}_{2}$ aqueous solution is obtained at $\mathrm{pH} 7$ for all initial lead concentrations. This result is valid for activated carbon used. It assumed that several lead species, such as $\mathrm{Pb}^{2+}, \mathrm{Pb}(\mathrm{OH})^{+}$and $\mathrm{Pb}_{3}(\mathrm{OH})_{4}{ }^{2+}$, may be present in aqueous solution. $\mathrm{Pb}$ (II) predominantly appears as $\mathrm{Pb}^{2+}$ at $\mathrm{pH}<6$ [18]. As $\mathrm{pH}$ is increased or hydrogen ions concentration is decreased, the reaction is shifted from left to right, and results in the formation of higher density of surface complexes and higher level of lead removal [6]. At $\mathrm{pH} 4, \mathrm{~Pb}^{2+}$ is the main lead species present in aqueous solution. The lead ion adsorption at $\mathrm{pH} 4$ can be ascribed to the electrostatic attraction between $\mathrm{Pb}^{2+}$ cations and the protonated surfaces of the activated carbons. The acidic groups on surface of activated carbon are present in the protonated forms at $\mathrm{pH}$ 4. Therefore, the uptake of $\mathrm{Pb}(\mathrm{II})$ is hindered due to electrostatic attraction. However, it was suggested that lead adsorption occurs at $\mathrm{pH} 4$. Lead ion is retained on activated carbon due to the mechanisms differ from ion exchange [7].

\subsection{Effect of Contact Time on Concentration and Adsorption Capacity}

The adsorption capacity of the lead on coconut leaves derived activated carbon increased with time. This result is in agreement with the work of Imamoglu and
Tekir [12], who demonstrated that there are enough adsorption sites to efficiently adsorb lead at lower initial concentration. However, lead concentration adsorption capacity reaches the equilibrium of $122.8 \mathrm{ppm}$ for $120 \mathrm{~min}$. The adsorption of lead ion on coconut leaves based activated carbon was found good at $323 \mathrm{~K}$ and found suitably good at 313, 333 and $343 \mathrm{~K}$. Thus, the results indicate that activated carbon produced from coconut leaves residue with $\mathrm{H}_{3} \mathrm{PO}_{4}$ activation is an effective adsorbent for the removal of lead from aqueous solutions. The concentration of lead on adsorption of coconut leaves decreases from $\mathrm{Pb}$ (II) chloride solution (solute concentration) till $122.8 \mathrm{ppm}$ within $313-343 \mathrm{~K}$. An increased percentage removal of $\mathrm{Pb}(\mathrm{II})$ from 75 to $94.75 \%$ is observed with $2 \mathrm{~g}$ of the adsorbent during agitation time of $160 \mathrm{~min}$ when the initial concentration of the higher uptake of $\mathrm{Pb}(\mathrm{II})$ chloride at low concentration may be attributed to the availability of more active centers on the surface of the adsorbent for lesser number of adsorbate species. $\mathrm{Pb}$ (II) chloride adsorption curves are single, smooth and continuous (Fig. 5) suggesting the possible monolayer coverage of lead molecules on the surface of the adsorbent.

\subsection{Kinetic Models}

In order to investigate the mechanism of sorption and potential controlling steps such as mass transport, several kinetic models were tested including the pseudo-first order kinetic model and the pseudo-second order kinetic model for a batch contact time process, where the rate of sorption of lead on to the given adsorbent is proportional to the amount of lead sorbed from the solution phase. The rate constants for the respective equations were found at four different temperatures. The pseudo-first order kinetics plots and the pseudo-second order kinetics plots for lead metal with adsorbates using an adsorbent $\left(\mathrm{CL}_{3}\right)$ activated carbon are presented below in Figs. 6 and 7.

\subsubsection{Pseudo-first order kinetic model}

Fig. 6 shows a plot of the Lagergren equation for the results of $\mathrm{Pb}(\mathrm{II})$ ion adsorption on $\left(\mathrm{CL}_{3}\right)$ activated carbon in the form of the pseudo-first order equation. In this case, a linear relationship was obtained between $\ln \left(q_{e}-q_{t}\right)$ and agitation time over whole sorption period with high correlation coefficient $(0.9378)$ as shown in Table 2. It is clear that the pseudo-first order equation describes the kinetics of sorption of $\mathrm{Pb}$ (II) on adsorbent $\left(\mathrm{CL}_{3}\right)$. However, the pseudo-first order equation does not provide any mechanistic evidence.

\subsubsection{Pseudo-second order kinetic model}

In Fig. 7 the plots show the pseudo-second order equations for the adsorption of lead metal. There are good 
correlation coefficients (0.9508). It is possible to ascertain from this model if the rate determining process is a chemical reaction or not. Thus, with the increase in the initial lead concentration within 313-343 K the amount of $\mathrm{Pb}$ (II) sorbed increases and then decreases. This is obvious for higher initial concentration values. More efficient utilization of the sorptive capacities of the sorbent would be expected due to greater sorption driving force, which is observed at $323 \mathrm{~K}$.

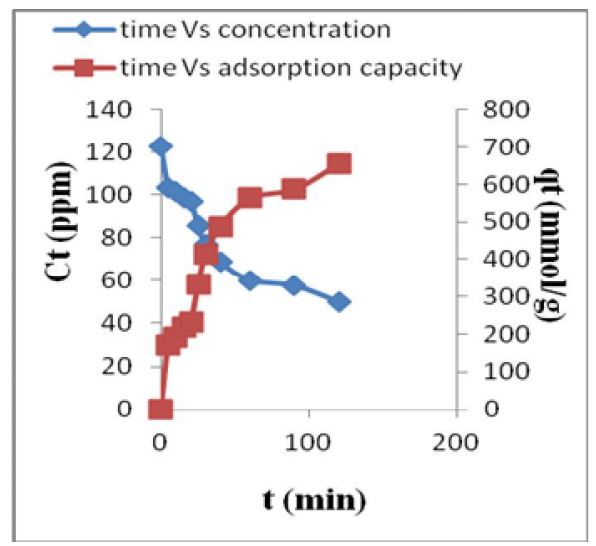

a)

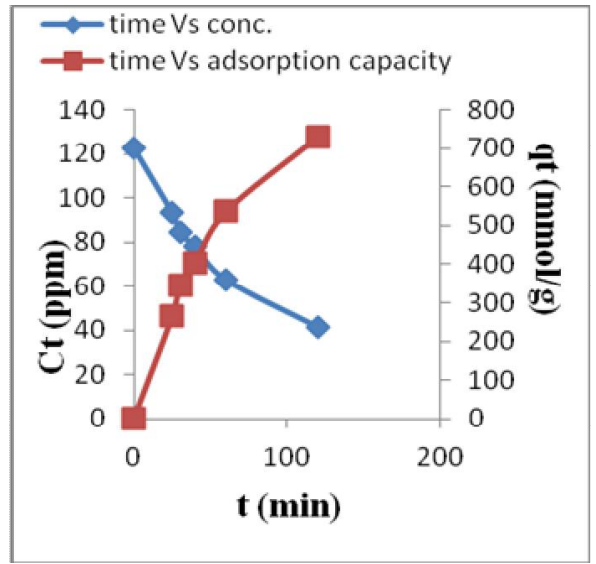

c)

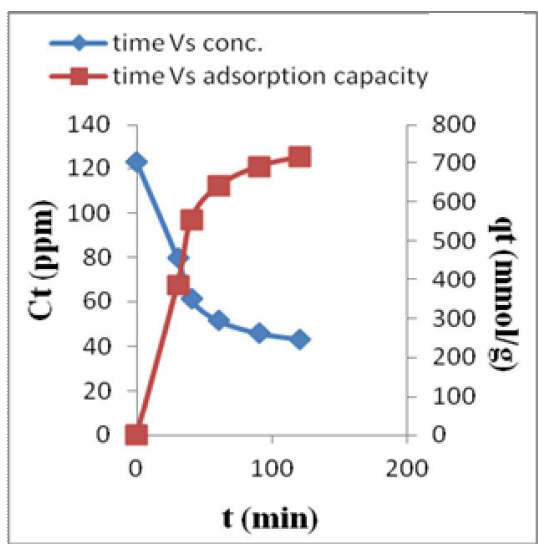

b)

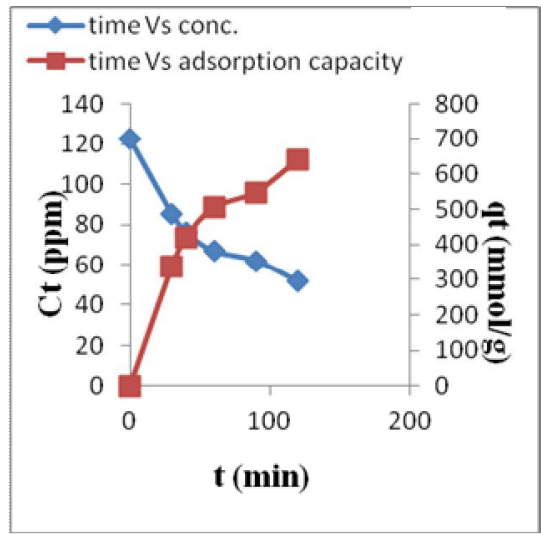

d)

Fig. 5. Variation in concentration of lead metal and adsorption capacity of carbon from coconut leaves with time at different temperatures (K): 313 (a); 323 (b); 333 (c) and 343 (d). Batch conditions: adsorbent weight is $0.02 \mathrm{~g}$, adsorbate volume is $180 \mathrm{~cm}^{3}$, adsorption time is $2 \mathrm{~h}$

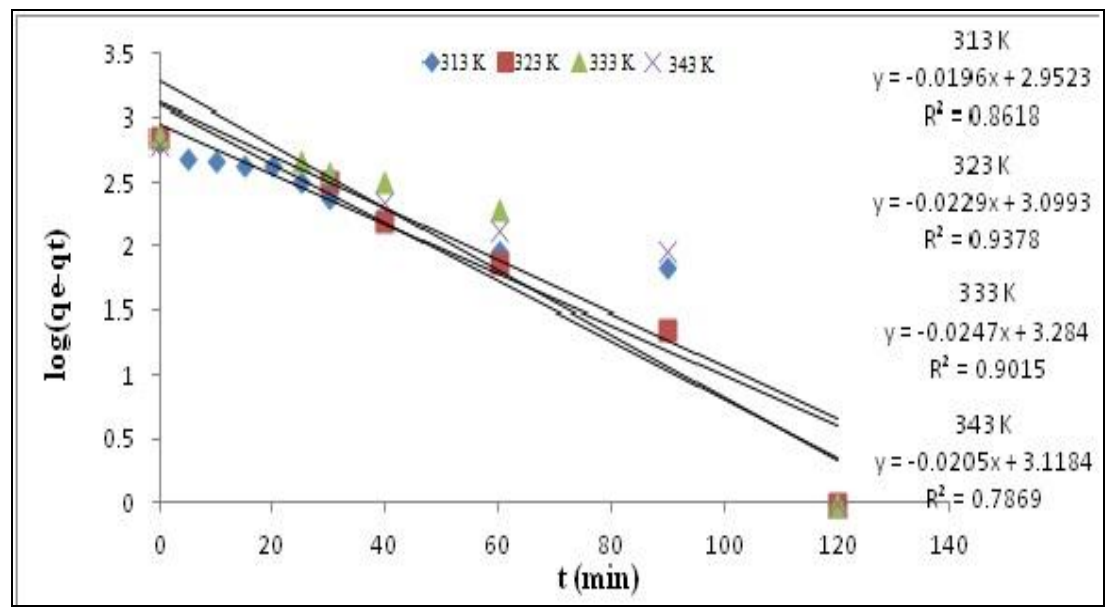

Fig. 6. The pseudo-first order model for the adsorption of lead metal on activated carbon from coconut leaf at different temperatures 


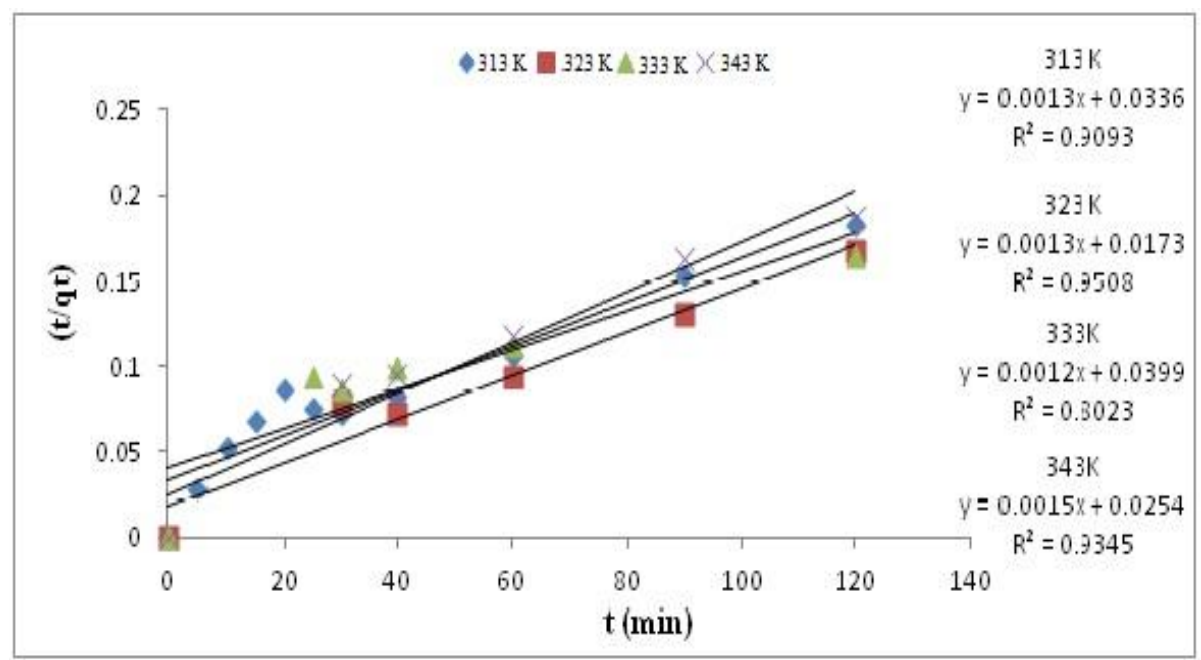

Fig. 7. The pseudo second-order model for the adsorption of lead metal on activated carbon from coconut leaf at different temperatures

The pseudo-first order and the pseudo-second order kinetic constants for adsorption of lead metal with using adsorbent $\left(\mathrm{CL}_{3}\right)$ at different temperatures

\begin{tabular}{|c|c|c|c|c|c|}
\hline \multirow{2}{*}{$T, \mathrm{~K}$} & \multicolumn{4}{|c|}{ Adsorbate $\mathrm{PbCl}_{2}$} \\
\cline { 2 - 6 } & \multicolumn{2}{|c|}{$\begin{array}{c}\text { The pseudo-first order } \\
\log \left(q_{e}-q_{t}\right)=\log \left(q_{e}-k_{2} t\right)\end{array}$} & \multicolumn{3}{c|}{$\left(1 / k_{3} q_{e}+t / q_{e}\right)$} \\
\hline 313 & $k_{2}$ & $R^{2}$ & $q_{e}$ & $k_{3}$ & $R^{2}$ \\
\hline 323 & 0.0196 & 0.8618 & 769.23 & 0.000143 & 0.9888 \\
\hline 333 & 0.0229 & 0.9378 & 909.09 & 0.0000478 & 0.9307 \\
\hline 343 & 0.0247 & 0.9015 & 833.33 & 0.0000637 & 0.9544 \\
\hline & 0.0205 & 0.7869 & 769.23 & 0.000126 & 0.9841 \\
\hline
\end{tabular}

It is observed from Table 2 that for both kinetic models the correlation coefficients $R^{2}$ is close to one. For the pseudo-first-order model, it was attributed to the fast initial uptake of $\mathrm{Pb}(\mathrm{II})$. The pseudo-second-order equation fitted the experimental data well. Correlation coefficient $R^{2}$ increases to 0.9841 as compared with that of the pseudo-first order kinetics model. This was confirmed by plotting graphs and comparing the linearized form of rate equation with the equation $y=m x+c$. Thus, by plotting $t / q_{t} v s$. $t$ for the pseudo-second order rate equation the rate constant for the respective equations were found at four different temperatures. Hence, the pseudo-second order was found to be more suitable than the pseudo-first order.

\subsection{Isotherm Modeling}

\subsubsection{Langmuir isotherm}

The Langmuir isotherm model suggests that adsorption takes place as monolayer coverage on homogeneous surface containing a finite number of vacant sites energetically equivalent to each other in respect of adsorption phenomenon and with negligible interaction between adsorbed molecules. The Langmuir adsorption isotherm obtained after $120 \mathrm{~min}$ of agitation time is shown in Fig. 8. The value of $R_{L}<1$, obtained in this study indicates the applicability of Langmuir adsorption isotherm. Hence, the values are $0<R_{\mathrm{L}}<1$ and adsorption is favorable.

\subsubsection{Freundlich isotherm}

Freundlich isotherm shows reasonably good fit (Fig. 9). The Freundlich constant " $n$ " is known as adsorption intensity. The values of " $n$ " are greater than 1 , indicating that adsorption of the metals is feasible on all the adsorbents synthesized, the values of adsorption intensity $n<<1$ reveals the applicability of this adsorption isotherm. The values of $K_{F}$ are given in Table 3. The constant $K_{f}$ is an indicator of adsorption capacity. Temperature effects on the Freundlich parameters reveal decreasing trend in the adsorption capacity with the increase in temperature. However, it is observed that the variation in the adsorption intensity is negligible, while $1 / n$ denotes the strength of adsorption process. $n=1$ indicates that the partition between two phases does not 
depend on the concentration. Hence, $n>1$ and the value of $1 / n$ below 1 indicate a normal adsorption. Thus, from these indications, Freundlich isotherm shows normal adsorption as $1 / n$ values are below 1 . As the temperature increases, the change of constants $K_{F}$ and $n$ predict that the quantity adsorbed rises more slowly and higher pressures are required to saturate the surface. However, $K_{f}$ and $n$ are parameters characteristic of the sorbent-sorbate system, which are determined by data fitting, whereas linear regression is generally used to determine the parameters of kinetic and isotherm models. The linear least-squares method and the linearly transformed equations were widely used to correlate sorption data. $1 / n$ is known as a heterogeneity parameter; the smaller $1 / n$, the greater the heterogeneity. This expression reduces to a linear adsorption isotherm when $1 / n=1$. In this case $1 / n<1$, which indicates Freundlich adsorption does not fit a favorable sorption process [17].

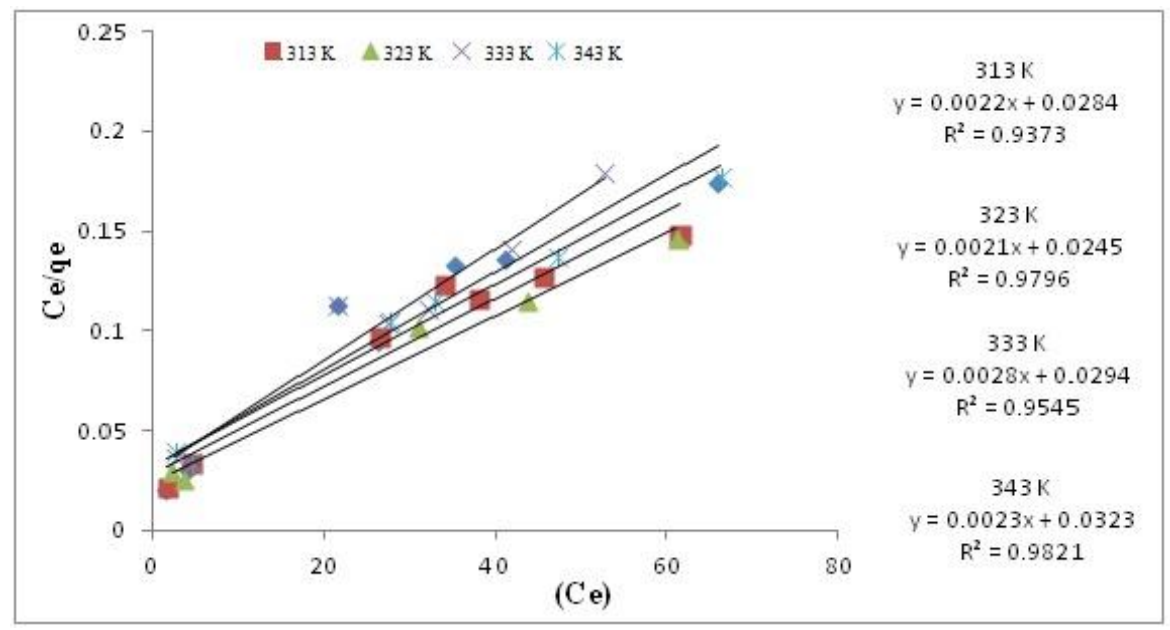

Fig. 8. Plots of $C_{e} / q_{e} v s . C_{e}$ for the adsorption of lead on activated carbon from coconut leaves $\left[\mathrm{CL}_{3}\right]$ at different temperatures

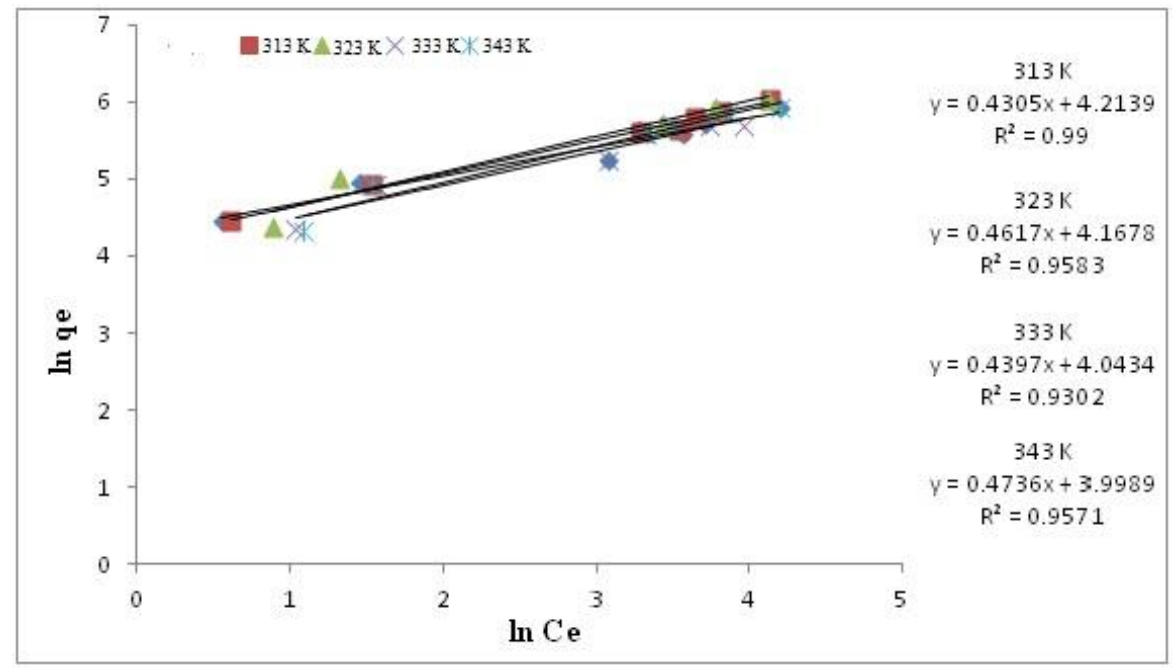

Fig. 9. Plots of $\ln q_{e} v s . \ln C_{e}$ for the adsorption of lead on activated carbon from coconut leaves $\left[\mathrm{CL}_{3}\right]$ at different temperatures

\subsubsection{Temkin isotherm}

Temkin isotherm also shows good results for $R^{2}$ value. On the other hand, while going through generalized isotherm it does not show good results for these experiments, as shown in Fig. 10. By ignoring the extremely low and large value of concentrations, the model assumes that heat of adsorption (function of temperature) of all molecules in the layer would decrease linearly rather than logarithmically with coverage.

Table 3 shows that the correlation coefficients $R^{2}$ of Langmuir isotherm for activated carbon obtained from 
coconut leaves is close to 1 , hence Langmuir isotherm gives best fit for the adsorption data. It simply means that the adsorption is restricted to monolayer capacity and metals are physically adsorbed. Values of " $b$ " exhibit the amount of binding energy and adsorption capacity of adsorbent. The fit of Langmuir isotherm indicates the homogenous nature of adsorbent surfaces.

\subsection{Thermodynamic Parameters}

$\Delta H$ and $\Delta S$ were obtained from the slope and intercept of Vant Hoff plot $\left(1 / T\right.$ vs. $\left.\ln K_{c}\right)$. Batch adsorption studies were carried out at 313, 323, 333 and
$343 \mathrm{~K}$ with of $\mathrm{Pb}$ solution $\mathrm{pH}$ equal to 6 . The initial concentration of $\mathrm{Pb}(\mathrm{II})$ chloride solution used was $20 \mathrm{ppm}$ with $0.5 \mathrm{~g}$ of the adsorbent. Table 4 gives the value of $\Delta G, \Delta S$ and $\Delta H$ for the adsorption of $\mathrm{Pb}(\mathrm{II})$. The negative values of free energy change $(\Delta G)$ indicate the feasibility and spontaneous nature of the adsorption of lead from $\mathrm{Pb}(\mathrm{II})$ chloride solution species [18]. The negative $\Delta H$ values of the process suggest the exothermic nature of adsorption of lead on activated carbon derived from coconut leaves. The negative value of $\Delta S$ is due to the lower degree of disorderness of adsorbed molecules [19].

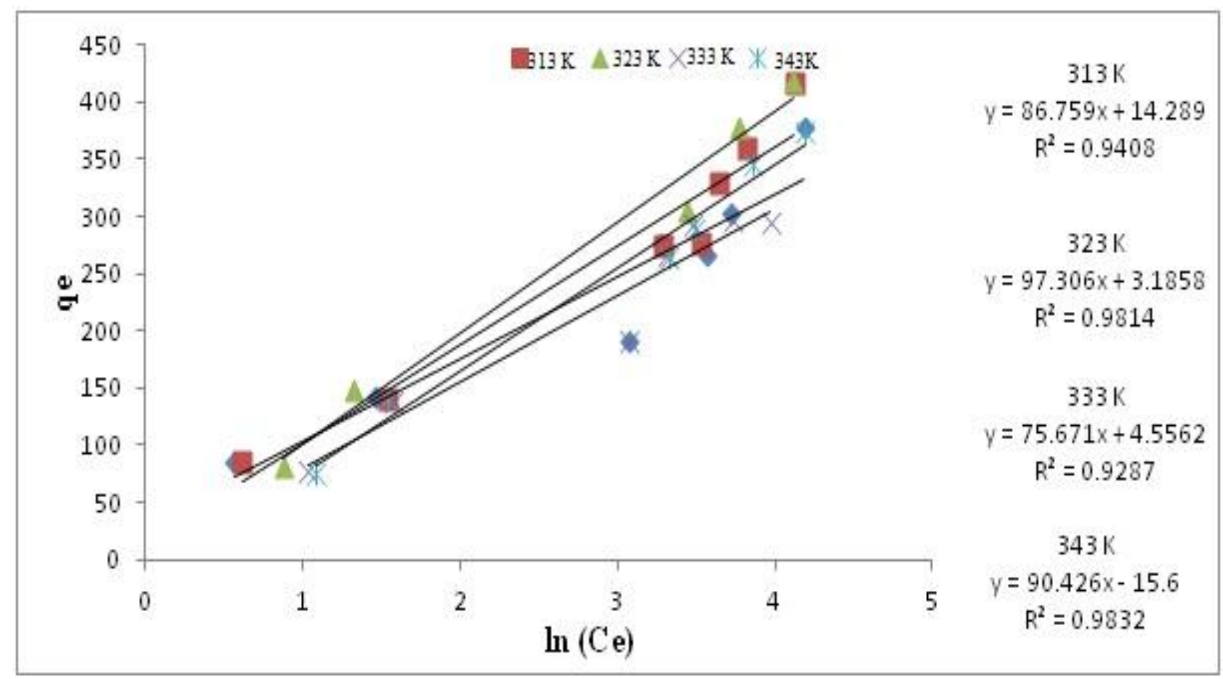

Fig. 10. Plots of $q_{e} v s . \ln C_{e}$ for the adsorption of lead on activated carbon from coconut leaves $\left[\mathrm{CL}_{3}\right]$ at different temperatures

Table 3

Constants of Langmuir, Freundlich and Temkin adsorption isotherm models for the adsorption of lead on activated carbon derived from coconut leaves (CL-03) at different temperatures

\begin{tabular}{|c|c|c|c|c|c|c|c|c|c|}
\hline \multirow{3}{*}{$T, \mathrm{~K}$} & \multicolumn{9}{|c|}{ Adsorbate $\mathrm{PbCl}_{2}$} \\
\hline & \multicolumn{3}{|c|}{$\begin{array}{c}\text { Langmuir } \\
1 / q_{e}=1 /(b V m) 1 / C_{e}+C_{e} / V_{m}\end{array}$} & \multicolumn{3}{|c|}{$\begin{array}{l}\text { Freundlich } \\
q_{e}=K_{F} C_{e}^{1 / n}\end{array}$} & \multicolumn{3}{|c|}{$\begin{array}{c}\text { Temkin } \\
q_{e}=B \ln A+B \ln C_{e}\end{array}$} \\
\hline & $b$ & $V_{m}$ & $R^{2}$ & $n$ & $K_{F}$ & $R^{2}$ & $A$ & $B$ & $R^{2}$ \\
\hline 313 & 0.0774 & 454.545 & 0.9821 & 2.322 & 67.619 & 0.990 & 1.179 & 86.759 & 0.940 \\
\hline 323 & 0.0857 & 476.19 & 0.9796 & 2.165 & 64.573 & 0.9583 & 1.033 & 97.306 & 0.9814 \\
\hline 333 & 0.0952 & 357.142 & 0.9545 & 2.274 & 57.019 & 0.9302 & 1.062 & 75.671 & 0.9287 \\
\hline 343 & 0.0712 & 434.782 & 0.9373 & 2.111 & 54.538 & 0.9571 & 0.841 & 90.426 & 0.9832 \\
\hline
\end{tabular}

Table 4

Thermodynamic parameters for the adsorption of $\mathrm{Pb}(\mathrm{II})$ on activated carbon $\left(\mathrm{CL}_{3}\right)$ derived from coconut leaves

\begin{tabular}{|c|c|c|c|}
\hline$T, \mathrm{~K}$ & $\Delta G, \mathrm{~kJ}$ & $\Delta S, \mathrm{~J} \mathrm{~K}^{-1}$ & $\Delta H, \mathrm{~kJ}$ \\
\hline 313 & -3000.0 & & -2.6231 \\
\hline 323 & -1600.2 & \multirow{3}{*}{-1.2062} & - \\
\hline 333 & -830.7 & & - \\
\hline 343 & -750.8 & & - \\
\hline
\end{tabular}




\section{Conclusions}

Coconut leaves activated carbon was prepared by synthesis with phosphoric acid. The adsorbents were investigated using scanning electron microscopy. The changes in their physical and chemical properties with increasing temperature were determined. Adsorption isotherms of lead metal on activated carbon from coconut leaves were generated and the kinetics of adsorption was studied. From the surface area analysis, adsorbent $\mathrm{CL}_{3}$ activated carbon exhibited higher surface area as compared to $\mathrm{CL}_{1}$ and $\mathrm{CL}_{2}$ adsorbents. Equilibrium of $\mathrm{Pb}$ (II) adsorption is reached after $120 \mathrm{~min}$. Langmuir isotherm model fitted better to the experimental data as compared to Freundlich and Temkin isotherms. This shows the adsorption is mono-layered and the adsorption sites are homogenous. Also, the Freundlich constant " $n$ " is greater than "one" for the synthesized adsorbents and thus was found to be reasonably suitable. The pseudo-second order was considered the most appropriate due to high correlation coefficient. This indicates that the reaction rate depends on concentration of lead and number of active sites in the adsorbents. The adsorption of $\mathrm{Pb}$ (II) onto $\mathrm{CL}_{3}$ activated carbon is an exothermic reaction based on enthalpy change values.

\section{References}

[1] Bhattacharya A., Venkobachar C.: J. Environ. Eng., 1984, 110, 110. https://doi.org/10.1061/(ASCE)0733-9372(1984)110:1(110)

[2] Xu T., Liu X.: Chinese J. Chem. Eng., 2008, 16, 401. https://doi.org/10.1016/S1004-9541(08)60096-8

[3] Jusoh A., Shiung L., Ali N. et al.: Desalination, 2007, 9, 206. https://doi.org/10.1016/j.desal.2006.04.048

[4] Acharya J., Sahu J., Mohanty C., Meikap B.: Chem. Eng. J., 2009, 149, 249. http//doi.org/10.1016/j.cej.2008.10.029

[5] Olorundare O., Krause R., Okonkwo J.: Phys. Chem. Earth

A/B/C, 2012, 50, 104. https://doi.org/10.1016/j.pce.2012.06.001

[6] Chen J., Wang X.: Sep. Purif. Technol., 2000, 19, 157.

https://doi.org/10.1016/S1383-5866(99)00069-6

[7] Zhang K., Cheung W., Valix M.: Chemosphere, 2005, 50, 1129. https://doi.org/10.1016/j.chemosphere.2004.12.059

[8] Sekar M., Sakthi V., Rengaraj S.: J. Colloid Interf. Sci., 2004, 279, 307. https://doi.org/10.1016/j.jcis.2004.06.042
[9] Boudrahem F., Aissani-Benissad F., Ait-Amar H.: J. Environ. Manage., 2009, 90, 3031.

https//doi.org./10.1016/j.jenvman.2009.04.005

[10] Depci T., Kul A., Onal Y.: Chem. Eng. J., 2012, 224, 200. https// doi.org./10.1016/j.cej.2012.06.077

[11] Chien S., Clayton W.: Soil Sci. Soc. Am. J., 1980, 44, 265. https://doi.org/10.2136/sssaj1980.03615995004400020013x [12] Imamoglu M., Tekir O.: Desalination, 2008, 228, 108. https//doi:10.1016/j.desal.2007.08.011

[13] Singh C., Sahu J., Mahalik K. et al.: J. Hazard. Mater., 2008, 153, 221. https//doi.org/10.1016/j.jhazmat.2007.08.043

[14] Issabayeva G., Aroua M., Sulaiman N.: J. Hazard. Mater., 2008, 155, 109. https://doi.org/10.1016/j.jhazmat.2007.11.036

[15] Momčilović M., Purenović M., Bojić A. et.al.: Desalination, 2011, 276, 53. https://doi.org/10.1016/j.desal.2011.03.013

[16] Issabayeva G., Aroua M., Sulaiman N.: J. Hazard. Mater., 2008, 155, 109. https// 10.1016/j.jhazmat.2007.11.036

[17] Deliyanni E., Kyzas G., Triantafyllidis K., Matis K.: Open Chem., 2015, 13, 699. https://doi.org/10.1515/chem-2015-0087 [18] S. Z. Mohammadi, M. A. Karimi, D. Afzali, F. Mansouri, Desalination 262 (2010) 86 https://doi.org/10.1016/j.desal.2010.05.048

[19] Gupta V., Mohan D., Sharma S., Park K.: The Environmentalist, 1999, 19, 129. https://doi.org/10.1023/A:1006693017711

Received: November 26, 2018 / Revised: January 15, 2019 / Accepted: June 02, 2019

\section{АДСОРБЦІ ВАЖКОГО МЕТАЛУ НА АКТИВОВАНОМУ ВУГІЛЛІ, ОТРИМАНОМУ 3 АГРОВІДХОДІВ КОКОСОВОГО ЛИСТЯ}

Анотація. Повільним піролізом за $673 \mathrm{~K}$ в інертній атмосфері одержано активоване вугілля з кокосового листя. Стехіометричне співвідношення приготовлених зразків становило 1:1 (CL1), 2:1 (CL2) i 3:1 (CL3). Коефіuієнт 3:1 визначено найкрашим для подальших досліджень. За методом БЕТ встановлено, що площа поверхні активованого вугілля CL3 1060,57 $\mathrm{M}^{2} / 2$ є більшою у порівнянні з вугіллям CL1 $i$ CL2. Адсорбиійні дослідження проводились за концентрачії речовин (2,5-122,8 мг/л) і температури розчину 313-343 К. Проведено дослідження ізотерм Ленгмюра, Фрейндліха $i$ Темкіна. Експериментальні дані дуже добре узгоджуються 3 рівняннями псевдо-першого та псевдо-другого порядку. Показано, що активоване вугілля CL3 можливо використовувати як сорбент для видалення свинияю з стічних вод.

Ключові слова: $Р b(I I)$, листя кокосу, псевдо-перший порядок, псевдо-другий порядок, ізотерма Ленгмюра, ізотерма Фрейндліха, ізотерма Темкіна. 